\title{
Erratum to: Hepatitis E Virus in Farmed Rabbits, Wild Rabbits and Petting Farm Rabbits in the Netherlands
}

\author{
Sara A. Burt ${ }^{1} \cdot$ Jorg Veltman $^{1} \cdot$ Renate Hakze-van der Honing $^{2} \cdot$ Heike Schmitt $^{1}$ \\ Wim H. M. van der Poel ${ }^{2}$
}

Published online: 30 August 2016

(C) The Author(s) 2016. This article is published with open access at Springerlink.com

\section{Erratum to: Food Environ Virol (2016) 8:227-229}

\section{DOI 10.1007/s12560-016-9239-3}

The original version of this article unfortunately contained a mistake. In the Abstract, the HEV prevalence in Farmed Rabbits, Wild Rabbits and Petting Farm Rabbits has been stated as " $(23,0$, and $60 \%$ respectively $)$ ". This should be: " $(0,60$, and $23 \%$ respectively)".

The online version of the original article can be found under doi:10.1007/s12560-016-9239-3.

Sara A. Burt

s.a.burt@uu.nl

1 Institute for Risk Assessment Sciences - Veterinary Public

Health Division, Faculty of Veterinary Medicine, Utrecht

University, PO Box 80175, 3508TD Utrecht,

The Netherlands

2 Department of Virology, Central Veterinary Institute, Wageningen University Research, Edelhertweg 15,

8219PH Lelystad, The Netherlands 